\title{
Does belief in free will make us feel good and satisfied?
}

\section{BACKGROUND}

Recent studies have shown that maintaining a strong belief in free will may be associated with well-being at the workplace (Stillman, Baumeister, Vohs, Lambert, Fincham, \& Brawer, 2010), more frequent attainment of pursued goals and emotional stability (Stillman, Baumeister, \& Mele, 2011).

\section{PARTICIPANTS AND PROCEDURE}

Two studies were conducted to investigate to what extent belief in free will (as opposed to belief in determinism) may be a good predictor of subjective well-being and ill-being (poor health condition). Study 1 investigated a sample of employees $(N=214)$ : 106 women and 108 men. The second research was conducted among 436 students: 236 women and 198 men.

\section{RESULTS}

The results of study 1 showed that those who believe in free will are satisfied with their lives and feel healthy. The results of study 2 showed that those who believe in free will feel better (have more positive emotions) and are more satisfied with their lives than those who believe in determinism.

\section{CONCLUSIONS}

Belief in free will has the potential for improving subjective well-being and belief in determinism (fate) lowers subjective well-being. What is more, the current study has also confirmed the results obtained by other researchers (Paulhus \& Carey, 1994, Carey \& Paulhus, 2013). The reliability of the free will subscale was replicated. Also, we confirmed a positive correlation between belief in free will and unpredictability, and between fatalistic determinism and unpredictability. The results of the present research proved that there is a need to develop and to promote belief in free will in societies and social policies because it can increase well-being.

\section{KEY WORDS}

health; subjective well-being; belief in free will; belief in determinism

Organization - University of Gdansk, Gdansk, Poland

Authors' Contributions - A: Study design · B: Data collection - C: Statistical analysis · D: Data interpretation ·

E: Manuscript preparation · F: Literature search · G: Funds collection

CORRESPONDING AUTHOR - Kondratowicz-Nowak, B. B., Institute of Psychology, University of Gdansk, 4 Bażyńskiego Str., 80-309 Gdańsk, Poland, e-mail: blanka.k@o2.pl

To CITE THIS ARTICLE - Kondratowicz-Nowak, B. B., \& Zawadzka, A. M. (2018). Does belief in free will make us feel good

and satisfied? Health Psychology Report, 6(2), 109-117. doi: https://doi.org/10.5114/hpr.2018.73053

RECEIVED 02.01.2017 · REVIEWED 05.03.2017 · ACCEPTED 04.05.2017 · PUBLISHED 24.01.2018. 


\section{BACKGROUND}

Researchers have long been looking into the question of sources of well-being and ways to increase its level. It would be interesting to find out about belief in free will, understood as a sense of responsibility for one's actions (cf. Paulhus \& Carey, 2011), in the context of potential sources of human well-being. However, research into the relationship between belief in free will and various aspects of psychological well-being is relatively scarce and has been conducted in laboratory settings only.

In this paper we attempt to answer the question of whether belief in free will is connected with well-being and, if so, in what way.

The present research has several valuable contributions to the current state of knowledge. We have extended the scope of existing studies to include the relationship between belief in free will vs. belief in determinism and subjective well-being. We have also enriched the examined samples, including Americans and Chinese, by adding a Polish one. Another novelty is that we have analyzed the relationship between belief in free will and ill-being (poor health condition). And finally, we have also gone beyond laboratory settings and incorporated both students and working adults into the research.

\section{THEORETICAL BACKGROUND}

There are two main approaches, i.e. eudaimonic and hedonistic, in the discussion of the topic of well-being. In the eudaimonic approach well-being is seen as living one's life in accordance with one's potential. This approach indicates that developing certain individual inner qualities (i.e. virtues directed towards intrinsic goals: competence, autonomy, relatedness) leads to increased well-being (Ryff, 1989; Seligman \& Csikszentmihalyi, 2000; Ryan \& Deci, 2000). In the hedonistic approach well-being is understood as subjective well-being (i.e. the way a person thinks and feels about her/his life), which consists of two components: cognitive well-being (i.e. evaluation of satisfaction with life as a whole and its domains) and affective well-being (i.e. positive and negative emotions, moods, feelings) (Diener, 1984; Dienier, Suh, Lucas, \& Smith, 1999).

Delroy Paulhus and Jasmine Carey (2011) define belief in free will as the responsibility for one's actions. Belief in free will is conceptually related to other beliefs: belief in determinism (including scientific determinism, i.e. belief in scientific causes of events, and fatalistic determinism, i.e. belief in minimal control and predetermined future) and belief in unpredictability (belief that all events happen at random). These are contrary to belief in free will because they indicate that all behavior is caused by preceding factors and is unpredictable (Paulhus \& Carey, 2011).
There is a relationship between holding a belief in free will and manifestation of pro-social behavior. This means that pro-social behavior may indirectly affect satisfaction with one's life through fulfillment of intrinsic goals, e.g. relatedness. Researchers have shown that people who believe in free will are more willing to help others and less aggressive, while those with a deterministic approach to life are less willing to help others and more aggressive (Baumeister, Masicampo, \& Dewall, 2009). Similar results were obtained by Kathleen Vohs and Jonathan Schooler (2008), whose experimental research demonstrated that belief in free will is positively associated with a lower level of cheating as compared to individuals with a deterministic approach to life, who tend to be more prone to cheating. Other studies demonstrated that both belief in free will and determinism are linked to conformism. Their results indicated that individuals holding a belief in free will tend to be less conformist as compared to those who do not believe in free will (Alquist, Ainsworth, \& Baumeister, 2013). Some other research tested the relationship between belief in free will and the sense of gratitude. The results showed that participants who believed in free will more frequently reported experiencing a feeling of gratitude than those who did not hold the belief. What is more, they also felt more grateful as compared to those who did not believe in free will. Moreover, when belief in free will was reduced in an experimental setting, the feeling of gratitude was weaker (MacKenzie, Vohs, \& Baumeister, 2014). Other researchers also confirmed the positive influence of belief in free will on human behavior. Stillman and colleagues showed that people holding a belief in free will focus on positive aspects of their actions and on the ability to rise above the circumstances, achieve pursued goals more frequently, and act in a way that is harmless to other social groups (2011). Stillman and colleagues also indicated that a strong belief in free will is associated with the attainment of pursued goals, conscious thoughts and deliberation (Stillman, et al., 2011). In another study they observed that a strong belief in free will is positively related to expected job performance (i.e. future success in the workplace), is positively liked to performance at the workplace (i.e. the effort put into a task, a positive influence on co-workers) and is positively related to emotional stability (Stillman, et al., 2010).

At this point, it should be noted that there are relatively few studies investigating the direct impact of belief in free will on subjective well-being. In fact, there are only two comprehensive studies examining this relationship. In the first study, on a sample of American students, Crescioni and colleagues (2016) found that belief in free will is positively correlated with a high level of gratitude, satisfaction with life, and perceived meaning of life, and is negatively correlated with the level of perceived stress. In the 
second study, on a sample of Chinese adolescents, Li and colleagues (2017) found that belief in free will is positively related to positive emotions and satisfaction with life and is negatively related to negative emotions. Moreover, free will believers have a higher level of satisfaction with life and positive emotions and a lower level of negative emotions as compared to believers in determinism.

\section{THE PRESENT RESEARCH}

In the present research we examined the relationship between belief in free will and subjective well-being. We conducted two studies: study 1 tested the link between belief in free will and cognitive well-being and the link between belief in free will and ill-being (i.e. poor health condition); study 2 examined the relationship between belief in free will and both cognitive and affective well-being vs. the relationship between belief in determinism and both cognitive and affective well-being. The research on the relationship between belief in free will and subjective well-being so far has included American and Chinese samples. These two cultures have been formed by different philosophical and religious systems than Polish culture. The American social system was built on the Protestant work ethic, whose foundations were laid by Calvinism, and the concept of predestination. The Chinese social system was built on Confucianism, imposing on its people absolute subservience to authority and social hierarchy. Our study was carried out on a Polish sample. Polish culture was shaped by Catholicism, which assumes that humans have free will.

On the basis of the previous research findings presented in the theoretical background above, i.e. that belief in free will is associated with higher well-being (life satisfaction and higher positive affect) (Crescioni et al., 2016; Li et al., 2017), we hypothesized as follows:

H1: Belief in free will increases the level of both cognitive and affective well-being, and decreases ill-being (poor health condition).

H2: Belief in determinism, as opposed to belief in free will, decreases both cognitive and affective well-being.

\section{STUDY 1. FREE WILL AND COGNITIVE WELL-BEING VS. ILL-BEING}

The aim of study 1 , a preliminary study, was to examine whether belief in free will is related to the selected measures of subjective well-being and, if so, in what way. We assumed (H1) that belief in free will increases cognitive well-being and decreases ill-being (poor health condition).

\section{PARTICIPANTS}

Two hundred and fourteen full-time or part-time employees, 106 women and 108 men of average age $M=34.19(S D=10.09)$, took part in the study. They varied in terms of their education: vocational training $5.10 \%$, secondary education $25.20 \%$, bachelor's degree $19.60 \%$, master's degree $44.40 \%$, and $5.70 \%$ did not provide information. All participants were inhabitants of northern Poland.

\section{PROCEDURE}

FAD-Plus Scale (by Paulhus \& Carey, 2011). One of four subscales of FAD-Plus, belief in free will, was used (the scale is described in detail in study 2 below). The belief in free will subscale (FW) consists of 7 pro-trait items, e.g.: Strength of mind can always overcome the body's desires, People must take full responsibility for any bad choices they make or Criminals are totally responsible for the bad things they do. Respondents indicate their answers on a 5-point scale from 1 (strongly disagree) to 5 (strongly agree). Cronbach's $\alpha$ for the free will subscale was $\alpha=.60$.

Cantril Self-Anchoring Striving Scale (Cantril, 1965). The Cantril Scale includes a question about a judgment of life and life evaluation (i.e. Please imagine a ladder with steps numbered from zero at the bottom to ten at the top. If the top step is 10 and the bottom step is 0 , on which step of the ladder do you feel you personally stand at the present time?). Respondents answer the questions on a 10-point scale from 0 (worst possible life) to 10 (best possible life).

Symptoms Check List (Czapiński \& Panek, 2009). The Symptoms Check List consists of 15 items. Using a 3-point scale (1 - never, 2 - less frequently than every 15 days, 3 - more often than twice a month), respondents indicate how often they have experienced each of the health problems on the list (e.g. upset stomach, headache, backache) within the last month. Cronbach's $\alpha$ for the scale was $\alpha=.80$.

We collected responses to the free will subscale of the FAD scale along with responses to the Cantril Scale and Symptom Check List (Czapiński \& Panek, 2009). Participants completed the questionnaires during small group (10-15 persons) sessions.

\section{RESULTS}

Table 1 presents descriptive statistics and reliabilities for each variable analyzed in study 1 . As we expected, cognitive well-being is positively correlated with belief in free will ( $r=.34, p=.010)$, while ill-being (poor health condition) is negatively correlated with belief in free will $(r=-.22, p=.010)$. These two correlations are statistically significant. There is no sig-
Does belief in free will make us feel good and satisfied? 
Table 1

Descriptive statistics and reliabilities for all variables analyzed in study 1

\begin{tabular}{lccc}
\hline Variable & $M$ & $S D$ & $\alpha$ \\
\hline Free will & 3.74 & 0.61 & .60 \\
Poor health condition & $3.66(\max =22)$ & 3.71 & .80 \\
Cognitive well-being & 7.48 & 1.34 & - \\
\hline
\end{tabular}

Table 2

Blanka Beata KondratowiczNowak, Anna Maria Zawadzka

Regression analysis coefficients with satisfaction of life and emotional balance as dependent variables, and cognitive well-being and ill-being (standard score) - study 1

\begin{tabular}{|c|c|c|c|c|c|c|c|}
\hline \multirow[t]{2}{*}{ Model } & \multirow[t]{2}{*}{ Independent variable } & \multicolumn{3}{|c|}{ Cognitive well-being } & \multicolumn{3}{|c|}{ III-being } \\
\hline & & $B$ & $t$ & $p$ & $B$ & $T$ & $p$ \\
\hline & Gender & .05 & 0.76 & n.s. & -.16 & -2.04 & .040 \\
\hline & Age & .01 & 0.79 & n.s. & -.09 & 1.03 & n.s. \\
\hline & Free will & .32 & 4.05 & $<.001$ & -.23 & -3.00 & .003 \\
\hline & & \multicolumn{3}{|c|}{$R=.33, R^{2}=.11$} & \multicolumn{3}{|c|}{$R=.29, R^{2}=.09$} \\
\hline
\end{tabular}

nificant relationship between belief in free will and age or gender.

Regression analysis (enter method) indicates that the model is statistically significant when the dependent variable is either cognitive well-being or ill-being (poor health condition) (see Table 2). Regression coefficient $\beta$ shows that belief in free will may be considered a good predictor of both cognitive well-being and ill-being (see Table 2). Moreover, the results show that men claim to experience health problems more often than women.

\section{STUDY 2. FREE WILL VS. DETERMINISM AND SUBJECTIVE (COGNITIVE AND AFFECTIVE) WELL-BEING}

Study 2 was conducted to verify the results of study 1 and to examine the relationship between: (H1) belief in free will and subjective well-being (both cognitive and affective) and (H2) belief in determinism and subjective well-being (both cognitive and affective).

\section{PARTICIPANTS}

Four hundred and thirty four students, 236 women and 198 men of average age $M=22.66(S D=4.74)$, took part in the study. They were students at the University of Gdansk (northern Poland) and Adam Mickiewicz University in Poznan (central Poland) and were awarded credits for participation in the study.

\section{PROCEDURE}

FAD-Plus scale (Paulhus \& Carey, 2011). The scale measures belief in free will and determinism. It consists of four subscales and includes 27 pro-trait items. Respondents indicate their answers on a 5-point scale from 1 (strongly disagree) to 5 (strongly agree). The first subscale, Free Will, includes 7 pro-trait items, e.g.: Strength of mind can always overcome the body's desires or People must take full responsibility for any bad choices they make. The second subscale, Fatalistic Determinism, includes 5 pro-trait items, e.g.: Fate already has a plan for everyone or Whatever will be, will be there's not much you can do about it. The third subscale, Scientific Determinism, consists of 7 pro-trait items, e.g.: Your genes determine your future or As with other animals, human behavior always follows the laws of nature. Finally, the fourth subscale, Unpredictability, consists of 8 pro-trait items, e.g.: Life seems unpredictable - just like throwing dice or flipping a coin or People's futures cannot be predicted. The original English version of the FAD-Plus scale demonstrated satisfactory internal consistency. Cronbach's $\alpha$ of the original scale was the least satisfactory ( $\alpha=.74$ to $\alpha=.69$ ) for Scientific Determinism (cf. Carey \& Paulhus, 2013).

For the purpose of this study, an experimental version of the scale was used (an adaptation by Kondratowicz-Nowak, Zawadzka, \& Wierzbicki, 2014). The FAD-Plus Polish language scale was translated from English into Polish and then from Polish into English (Konadratowicz-Nowak, Zawadzka, \& Wierzbicki, 2014; see Appendix Table 3 for Polish translation). Confirmation factor analysis was used to test the as- 
Table 3

Polish Translation of Paulus and Carey (2011) FAD-Plus Scale

\begin{tabular}{llll}
\hline Item & Sub- & Item in Polish & Item in English \\
No. & scale & \\
\hline
\end{tabular}

1.

5.

9. FD Nasze plany są zdeterminowane przez los

13.

17.

2.

6.

10.

14.

SD

18.

11.

15.

19.
Wierzę, że przyszłość jest zdeterminowana przez przeznaczenie

Nieważne, jak bardzo się starasz, nie możesz zmienić swojego przeznaczenia

Co ma być, to będzie - niewiele możesz z tym zrobić

Czy ludziom się to podoba, czy nie, tajemnicze siły kontrolują ich życie

Talenty i osobowość zależą od biologicznej natury człowieka

Psychologowie i psychiatrzy rozpracują wszelkie ludzkie zachowania

Twoja przyszłość zależy od twoich genów

Nauka pokazuje, w jaki sposób środowisko, w którym wzrastałeś, ukształtowało twoją obecną inteligencję i osobowość

Zachowania ludzi są zawsze zgodne z prawem natury, tak jak zachowania zwierząt

Charakter dzieci zależy od charakteru ich rodziców

Twoje dzieciństwo determinuje twój sukces jako osoby dorosłej

Głównie zdarzenia losowe wpływają na historię ludzkości na świecie

Życie wydaje się nieprzewidywalne dokładnie tak, jak rzucanie kostką do gry lub monetą

UP Ludzie są nieprzewidywalni

Życie jest trudne do przewidzenia, ponieważ prawie zawsze kieruje nim przypadek

To, czy ludzie mają szczęście, czy nie, ma duży wpływ na ich życie

To, co dzieje się z ludźmi, jest kwestią przypadku

Przyszłości ludzi nie da się przewidzieć
I believe that the future has already been determined by fate

No matter how hard you try, you can't change your destiny

Fate already has a plan for everyone

Whatever will be, will be - there's not much you can do about it

Whether people like it or not, mysterious forces seem to move their lives

People's biological makeup determines their talents and personality

Psychologists and psychiatrists will eventually figure out all human behavior

Your genes determine your future

Science has shown how your past environment created your current intelligence

As with other animals, human behavior always follows the laws of nature

Parents' character will determine the character of their children

Childhood environment will determine your success as an adult

Chance events seen to be a major cause of human history
Does belief in free will make us feel good and satisfied?

Nikt nie może przewidzieć tego, co się stanie No one can predict what will happen in this world

Life seems unpredictable - just like throwing dice or flipping a coin

People are unpredictable

Life is hard to predict because it is almost totally random

Luck plays a big role in people's lives

What happens to people is a matter of chance

People's futures cannot be predicted

(Table 3 continues) 
Table 3

(Table 3 continued)

\begin{tabular}{|c|c|c|c|c|}
\hline & $\begin{array}{l}\text { Item } \\
\text { No. }\end{array}$ & $\begin{array}{l}\text { Sub- } \\
\text { scale }\end{array}$ & Item in Polish & Item in English \\
\hline \multirow{7}{*}{$\begin{array}{r}\text { Blanka Beata } \\
\text { Kondratowicz- } \\
\text { Nowak, } \\
\text { Anna Maria } \\
\text { Zawadzka }\end{array}$} & 4. & \multirow{7}{*}{ FW } & Decyzje ludzi zależą od nich samych & $\begin{array}{l}\text { People have complete control over the } \\
\text { decisions they make }\end{array}$ \\
\hline & 8. & & $\begin{array}{l}\text { Ludzie muszą brać pełną odpowiedzialność } \\
\text { za wszystkie złe wybory, których dokonują }\end{array}$ & $\begin{array}{l}\text { People must take full responsibility for any } \\
\text { bad choices they make }\end{array}$ \\
\hline & 12. & & $\begin{array}{l}\text { Ludzie mogą przezwyciężyć wszystkie } \\
\text { przeszkody, jeśli naprawdę tego chcą }\end{array}$ & $\begin{array}{c}\text { People can overcome any obstacles if they } \\
\text { truly want to }\end{array}$ \\
\hline & 16. & & $\begin{array}{l}\text { Przestępcy są w pełni odpowiedzialni za złe } \\
\text { rzeczy, które robią }\end{array}$ & $\begin{array}{c}\text { Criminals are totally responsible for the bad } \\
\text { things they do }\end{array}$ \\
\hline & 21. & & Ludzie mają całkowicie wolną wolę & People have complete free will \\
\hline & 23. & & $\begin{array}{l}\text { Ludzie są zawsze sami winni swoich złych } \\
\text { czynów }\end{array}$ & $\begin{array}{c}\text { People are always at fault for their bad } \\
\text { behavior }\end{array}$ \\
\hline & 26. & & $\begin{array}{c}\text { Siła umysłu może zawsze poskromić } \\
\text { pragnienia ciała }\end{array}$ & $\begin{array}{c}\text { Strength of mind can always overcome the } \\
\text { body's desires }\end{array}$ \\
\hline
\end{tabular}

sumption about the four-factor solution model. The $\chi^{2}$ was significant $\chi^{2}(311, n=417)=680.97, p<.001$, CMIN/ DF was 2.19 and the root mean square residual (RMR) estimate was .08, the root mean square error of approximation (RMSEA) estimate was .05, PCLOSE $=.14$. The results indicate that a moderate fit of the tested four-factor solution model was obtained for the Polish sample.

External reliability with the NEO-FII test ( $\mathrm{Za}$ wadzki, et al., 1998) showed statistically significant relationships similar to those in the original version (cf. Carey \& Paulhus, 2013): a positive correlation between belief in Free Will and Extraversion $(r=.20$, $p<.001)$, Agreeableness $(r=.19, p<.001)$, Conscientiousness $(r=.19, p<.001)$; a positive correlation between Scientific Determinism and Neuroticism $(r=.15, p<.001)$; positive correlation between $\mathrm{Fa}-$ talistic Determinism and Openness to Experience $(r=-.21, p<.001)$, Neuroticism $(r=.19, p<.001)$ and positive relationship between Unpredictability and Neuroticism $(r=.12, p=.010)$, Conscientiousness $(r=.14, p=.005)$ and belief in a zero sum game

Table 4

Descriptive statistics and Cronbach's $\alpha-$ study 2

\begin{tabular}{lccc}
\hline Variable & $M$ & $S D$ & $\alpha$ \\
\hline Free will & 3.66 & 0.62 & .68 \\
Scientific determinism & 2.85 & 0.52 & .48 \\
Fatalistic determinism & 2.32 & 0.78 & .75 \\
Unpredictability & 3.39 & 0.57 & .67 \\
Emotional well-being & 0.54 & 0.52 & .77 \\
Cognitive well-being & 7.26 & 1.39 & .72 \\
\hline
\end{tabular}

$(r=.15, p<.001)$ (Kondratowicz-Nowak, Zawadzka, \& Wierzbicki, 2014).

Cronbach's $\alpha$ for each of the subscales in the present study is as follows: Free Will $\alpha=.68$; Scientific Determinism $\alpha=.48$; Fatalistic Determinism $\alpha=.75$; Unpredictability $\alpha=.67$. We excluded Scientific Determinism from further analysis since the reliability of this subscale was not satisfactory.

Cantril Self-Anchoring Striving Scale (Cantril, 1965). The Cantril Scale was used in this study in the same way as in study 1 .

Positive and Negative Affect Schedule (SUPIN version S20 - Polish adaptation Brzozowski, 2010). PANAS was used to measure positive affect (PA scale) and negative affect (NA scale). It consists of 20 emotions and feelings (e.g. nervous, strong, active, on one's mettle). Respondents indicate how they feel in general, usually by marking each of the 20 emotions and feelings on a 5-point scale $(1-$ very slightly or not at all, 2 - a little, 3 - moderately, 4 quite $a$ bit and 5 - extremely. In the current study we adopted emotional balance as an indicator of emotional well-being. Cronbach's $\alpha$ for the PA scale was $=.85$, and for the NA scale was $=.89$.

We collected responses to the FAD-Plus scale along with the Cantril Scale and PANAS scale. Participants completed the questionnaires during small group (10-15 persons) sessions.

\section{RESULTS}

Table 4 shows descriptive statistics and reliabilities for each variable analyzed in study 2 . Correlation analysis of the three FAD-Plus subscales shows that there is a significant negative correlation be- 
Table 5

Correlations between belief in free will vs. belief in determinism and subjective well-being

\begin{tabular}{lcccc}
\hline Dependent variable & FW & $S D$ & FD & UN \\
\hline Cognitive well-being & 0.07 & $-0.14^{* *}$ & $-0.10^{*}$ & -0.03 \\
Emotional well-being & $0.16^{* * *}$ & $-0.12^{*}$ & $-0.17^{* * *}$ & -0.07 \\
\hline
\end{tabular}

Note. Level of significance: ${ }^{*} p<.05 .{ }^{* *} p<.01 .{ }^{* * *} p<.001$.

tween free will and fatalistic determinism $(r=-.16$, $p<.001)$, but there is a positive correlation between belief in free will and unpredictability $(r=.12$, $p=.015)$ and between belief in scientific determinism and unpredictability $(r=.16, p<.001)$; and belief in fatalistic determinism and unpredictability $(r=.31$, $p<.001)$. As expected, belief in free will and affective well-being are positively related while fatalistic determinism is negatively correlated with affective well-being (see Table 5). Also, cognitive well-being is negatively correlated with belief in fatalistic determinism (see Table 5). The relationship between cognitive well-being and belief in free will is not statistically significant.

The results of this study also show statistically significant correlations between belief in free will and gender $(r=-.16, p<.001)$ and between belief in fatalistic determinism and gender $(r=.24, p<.001)$ and between belief in unpredictability and gender $(r=.10, p=.035)$. In the examined sample, belief in free will is more associated with being male and both belief in fatalistic determinism and unpredictability are more linked with being female. In study 2 , there is a significant negative relationship between belief in free will and age $(r=-.12, p=.016)$ but there is not a significant relationship between age and belief in fatalistic determinism or unpredictability.

Next, structural equation modeling (SEM) was applied to verify the hypotheses using AMOS 22 software (maximum likelihood method of analysis; see Figure 1). Belief in free will, fatalistic determinism and unpredictability were entered as predictors of latent construct reflecting subjective well-being.
The tested model proved to be a good fit to the data: $\chi^{2}(n=434, d f=6)=6.90, p=.330$; CFI $=0.99$; NFI $=0.95$, RMSEA $=.02$, PCLOSE $=.81$. The results demonstrated that increase in belief in free will $(\beta=.22, p<.001)$ and decrease in determinism (fatalistic) $(\beta=-.21, p<.001)$ are significantly related to increase in subjective well-being, i.e. increase in positive emotions $(\beta=.44, p<.001)$ and satisfaction with life $(\beta=.47, p<.001)$ and decrease in negative emotions $(\beta=-.51, p<.001)$. Unpredictability was not significantly related to subjective well-being. SEM analysis demonstrated that the assumptions about the relationships between belief in free will and subjective well-being (both cognitive and affective) (H1) and determinism and subjective well-being (both cognitive and affective) (H2) are confirmed.

\section{DISCUSSION}

Our research hypotheses have predominantly been confirmed: belief in free will is linked with an increase in subjective well-being. The results of study 1 show that free will believers are satisfied with life, and they feel healthy. Crescioni and colleagues (2016) obtained similar results: free will believers had higher satisfaction with life. The results of study 2 demonstrate that free will believers have more positive emotions than believers in determinism, who have more negative emotions and who are less satisfied with their lives. Analogical results were also announced by $\mathrm{Li}$ and colleagues (2017): free will believers had higher life satisfaction, and perceived

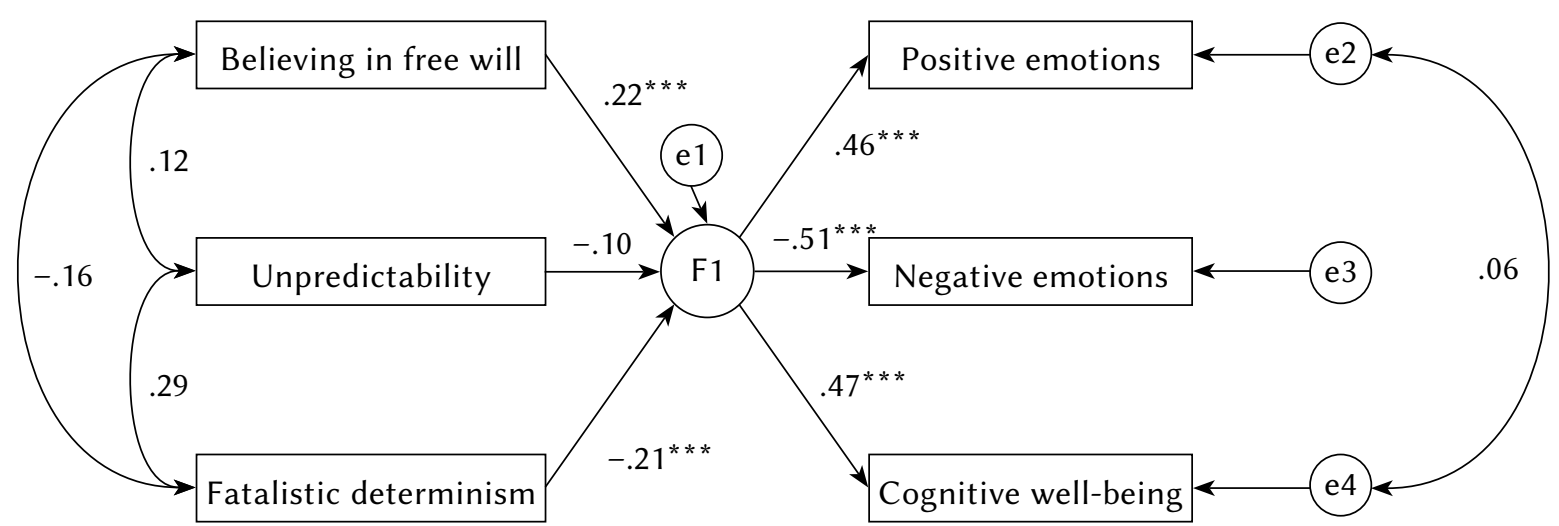

Figure 1. Structural equation model of factors associated with subjective well-being (F1) and free will, fatalistic determinism and unpredictability (standardized estimates). 
Blanka Beata KondratowiczNowak, Anna Maria Zawadzka more positive and less negative affect as compared to believers in determinism. Therefore, considering the results of both the present study and the two other studies (American and Chinese) discussed, we may conclude that belief in free will increases subjective well-being regardless of the cultural context. The present research has also extended the findings of previous research, which showed that free will believers have more pro-social tendencies - they are more helpful and more grateful, they cheat less and are less aggressive than non-free will believers (cf. Baumeister, Masicampo, \& Dewall, 2009; Stillman, et. al., 2010; MacKenzie et al., 2014). These pro-social tendencies assure good social relations, which subsequently increase well-being. Moreover, free will believers think more positively about their future careers and perform better at the workplace, and these again increase their well-being (cf. Stillman et al., 2010; Stillman, Baumeister, \& Mele, 2011). Belief in free will makes people see that there are various possibilities for them to choose from and that there are various ways to behave. Determinism, in contrast, limits people's choices and makes people accept as a fact that it is the preceding events that determine the situation. Therefore, our research confirms that life satisfaction, positive emotional state and better health are a likely outcome of belief in free will.

Moreover, the results demonstrated that although both free will and determinism are related to unpredictability, the relationship between determinism and unpredictability is much stronger. The diverse nature of these attitudes may explain why unpredictability is not linked to subjective well-being.

The results also showed that age and gender may be related to belief in free will, determinism and unpredictability in younger groups (i.e. students; study 2), but not in older groups (i.e. working adults; study 1). These results correspond to the results obtained in Chinese and American youth samples, which observed a positive relationship between belief in free will and subjective well-being (i.e. satisfaction with life). Therefore it would be interesting to undertake further examination of the issue of age, gender and changing life tasks and roles within the scope of belief in free will.

\section{LIMITATIONS OF THE PRESENT STUDIES AND DIRECTIONS FOR FUTURE RESEARCH}

The present study has several minor limitations. Firstly, the scientific determinism subscale of FAD-Plus used in study 2 was excluded from the analysis because of low reliability in the surveyed sample. Also, reliability of the belief in free will scale in study 1 (but not in study 2) was moderately satisfactory. Secondly, the complete FAD-Plus scale was tested in a group of students only (study 2); therefore it would be sensible to extend the research sample to other social groups, as well as extending the age range. Also, in connection with the conclusions, further research on the FAD-Plus scale should be conducted in order to evaluate the adequacy of external reliability. Thirdly, another limitation may be the fact that the survey was conducted on a sample of Polish subjects, who tend to be strong Catholic believers (see Carey \& Paulhus, 2013), and this may also affect belief in free will. Fourthly, it should also be noted that there may be a reverse causal relationship between belief in free will and subjective well-being. So, it would be advisable to test the opposite direction of this relationship and ask whether subjective well-being influences belief in free will and, if it does, in what way. Finally, future studies should also evaluate whether some important variables (e.g. self-esteem) may be mediators in the relationship between belief in free will and subjective well-being.

\section{CONCLUSIONS}

Despite the limitations listed above, which do not influence the findings concerning the main assumptions underlying the present study, we have demonstrated that, consistent with the assumptions, belief in free will has the potential for improving subjective well-being and that belief in determinism (fate) lowers subjective well-being. What is more, the current study has also confirmed the results obtained by other researchers (Paulhus \& Carey, 1994, 2011, 2013). The reliability of the free will subscale has been confirmed. Also positive correlations between belief in free will and unpredictability, and between fatalistic determinism and unpredictability, were replicated.

The results of the present research proved that there is a need to develop and to promote belief in free will in societies and social policies because it can increase well-being.

\section{References}

Alquist, J., Ainsworth, S., \& Baumeister, R. (2013). Determined to conform: disbelief in free will increases conformity. Journal of Experimental Social Psychology, 49, 80-86.

Baumeister, R. F., Masicampo, E. J., \& Dewall, C. N. (2009). Prosocial benefits of feeling free: disbelief in free will increases aggression and reduces helpfulness. Personality and Social Psychology Bulletin, 35, 260-268.

Brzozowski, P. (2010). Skala uczuć pozytywnych i negatywnych SUPIN. Polska adaptacja skali PANAS D. Watson i L.A. Clark [Positive and Neg- 
ative Affect: The Polish adaptation of PANAS Scales D. Watson i L.A. Clark]. Warszawa: Pracownia testów Psychologicznych Polskiego Towarzystwa Psychologicznego.

Cantril, H. (1965). Pattern of human concerns. New Jersey: Rutgers University Press

Carey, J. M., \& Paulhus, D. L. (2013). Worldview implications of believing in free will and/or determinism: politics, morality and punitiveness. Journal of Personality Assessment, 81, 130-141. doi: 10.1111/j.1467-6494.2012.00799.x

Crescioni, A. W., Baumeister, R. F., Ainsworth, S. E., Ent, M., \& Lambert, N. M. (2016). Subjective correlates and consequences of belief in free will. Philosophical Psychology, 29, 41-63.

Czapiński, J., \& Panek, T. (2009). Diagnoza spoteczna. Warunki i jakość życia Polaków [Social Diagnosis: objective and subjective quality of life in Poland]. Warszawa: Rada Monitoringu Społecznego.

Diener, E. (1984). Subjective well-being. Psychological Bulleting, 95, 542-575.

Dienier, E. Suh, E. M., Lucas R. E., \& Smith, H. L. (1999). Subjective well-being - three decades of progress. Psychological Bulletin, 125, 276-301.

Kondratowicz-Nowak, B., Zawadzka A. M., Wierzbicki, J. (2014). Przekonanie o posiadaniu wolnej woli i jego korelaty w kontekście pracy i organizacji [Belief in free will and its correlates in the context of work], referat wygłoszony na XXXV Zjeździe PTP, 18-21 września, Bydgoszcz.

Li, C., Wang, S., Zhao, Y., Kong, F., \& Li, J. (2017). The freedom to pursue happiness: Belief in free will predicts life satisfaction and positive affect among Chinese adolescents. Frontiers in Psychology, 7, 2027.

MacKenzie, M., Vohs, K., \& Baumeister, R. (2014). You don't have to do that: belief in free will promotes gratitude. Personality and Social Bulletin, 40, 1-12.

Paulhus, D. L., \& Margesson, A. (1994). Free Will and Scientific Determinism (FAD-4) scale. [Unpublished instrument]. Vancouver, BC, Canada: University of British Columbia.

Paulhus, D. L., \& Carey, J. M. (2011). The FAD-Plus: Measuring lay beliefs regarding free will and related constructs. Journal of Personality Assessment, 93, 96-104.

Ryan, R. M., \& Deci, E. L. (2000). Self-determination theory and the facilitaion of intrinsic motivation, social developmant, and well-being. American Psychologist, 55, 68-78.

Ryff, C. D. (1989). Happiness is everything, or is It? Explorations on the meaning of psychlogical well-being. Journal of Personality and Social Psychology, 57, 1069-1081.

Seligman, M. E. P., \& Csikszentmihalyi, M. (2000). Positive psychology. American Psychologist, 55, 5-14.

Stillman, T. F., Baumeister, R. F., \& Melle, A. R. (2011). Free will in everyday life: autobiographical ac- counts of free and unfree actions. Philosophical Psychology, 24, 381-394.

Stillman, T. F., Baumeister, R. F., Vohs, K. T., Lambert, N. M., Fincham, F. D., \& Brewer, L. E. (2010). Personal philosophy and personnel achievement: belief in free will predicts better job performance. Social Psychological and Personality Scince, 1, 43-50.

Vohs, K., \& Schooler, J. (2008). The value of believing in free will: Encouraging a belief in determinism increases cheating. Psychological Science, 19, 49-54. doi: 10.1111/j.1467-9280.2008.02045.x

Zawadzki, B., Strelau, J., Szczepaniak, P., \& Śliwińska, M. (2007). Inwentarz Osobowości NEO FFI Paula Costy i R. McCrae. Adaptacja polska [The NEO FFI Personality Inventory by Paul Costa \& R. McCrae. Polish adaptation]. Warszawa: Pracownia Testów Psychologicznych Polskiego Towarzystwa Psychologicznego.
Does belief in free will make us feel good and satisfied? 